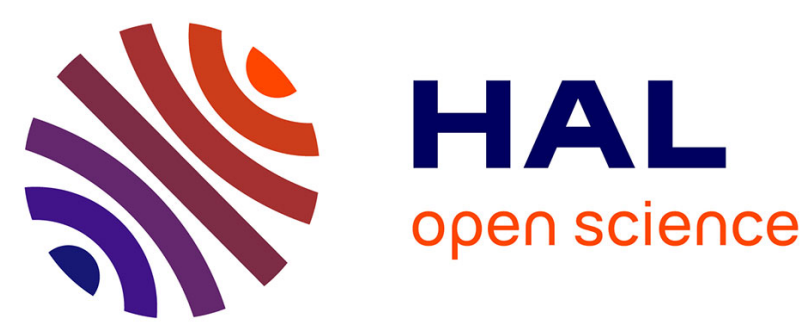

\title{
mutations in male breast cancer: a population-based study in Central Italy
}

Valentina Silvestri, Piera Rizzolo, Ines Zanna, Mario Falchetti, Giovanna

Masala, Simonetta Bianchi, Laura Papi, Giuseppe Giannini, Domenico Palli, Laura Ottini

\section{To cite this version:}

Valentina Silvestri, Piera Rizzolo, Ines Zanna, Mario Falchetti, Giovanna Masala, et al.. mutations in male breast cancer: a population-based study in Central Italy. Breast Cancer Research and Treatment, 2010, 122 (1), pp.299-301. 10.1007/s10549-010-0797-z . hal-00535447

\section{HAL Id: hal-00535447 https://hal.science/hal-00535447}

Submitted on 11 Nov 2010

HAL is a multi-disciplinary open access archive for the deposit and dissemination of scientific research documents, whether they are published or not. The documents may come from teaching and research institutions in France or abroad, or from public or private research centers.
L'archive ouverte pluridisciplinaire HAL, est destinée au dépôt et à la diffusion de documents scientifiques de niveau recherche, publiés ou non, émanant des établissements d'enseignement et de recherche français ou étrangers, des laboratoires publics ou privés. 


\title{
$P A L B 2$ mutations in male breast cancer: a population-based study in Central Italy
}

\author{
Valentina Silvestri · Piera Rizzolo • Ines Zanna • \\ Mario Falchetti · Giovanna Masala $\cdot$ Simonetta Bianchi • \\ Laura Papi · Giuseppe Giannini · Domenico Palli • \\ Laura Ottini
}

Received: 7 February 2010/Accepted: 9 February 2010/Published online: 24 February 2010

(C) Springer Science+Business Media, LLC. 2010

To the Editor,

Male breast cancer (MBC) is a rare disease compared to female breast cancer (FBC). However, MBC shares many similarities with FBC, including genetic predisposition factors such as BRCA1/2 mutations. The frequency of $B R C A 1 / 2$ mutations is quite different in ethnically diverse population- and clinic-based MBC series, ranging between 4 and $40 \%$ for $B R C A 2$ and up to $10 \%$ for $B R C A 1$ [1]. In a population-based series of $108 \mathrm{MBCs}$ from Central Italy, we reported that about $9 \%$ of MBCs were BRCAl/2 carriers [2], suggesting the contribution of additional susceptibility genes.

Several studies identify PALB2 as a moderate-penetrance breast cancer (BC) susceptibility gene, accounting for about $1 \%$ of $B R C A 1 / 2$ negative familial/early onset BCs [3, 4]. PALB2 mutations were found in families with both FBC and MBC cases, suggesting that $P A L B 2$ may be

Valentina Silvestri and Piera Rizzolo equally contributed to the work.

V. Silvestri · P. Rizzolo · M. Falchetti - G. Giannini ·

L. Ottini $(\square)$

Department of Experimental Medicine, "Sapienza"

University of Rome, 00161 Rome, Italy

e-mail: laura.ottini@uniroma1.it

I. Zanna - G. Masala - D. Palli

Molecular and Nutritional Epidemiology Unit, Cancer Research and Prevention Institute-ISPO, 50139 Florence, Italy

S. Bianchi

Department of Pathology, University of Florence, 50139 Florence, Italy

L. Papi

Medical Genetics Unit, Department of Clinical Physiopathology, University of Florence, 50139 Florence, Italy involved in MBC risk [3]. As for BRCA1/2, there are evidences that $P A L B 2$ might play a role in prostate cancer (PC) [5]. Interestingly, PC patients have an increased risk of $\mathrm{BC}[6]$ and, on the other hand, MBC patients show an increased risk of PC [7], suggesting that these tumours may share risk factors.

The role of $P A L B 2$ in MBC predisposition is still largely unknown. An interesting evaluation about this latter is provided in the recent article by Sauty de Chalon et al. [8]. Yet in the above mentioned study PALB2 pathogenic mutations were not found in $25 \mathrm{MBCs}$ belonging to 25 BRCA1/2 negative families and, based on PALB2 mutation frequency $(\sim 1 \%)$, it cannot be excluded that these findings may indeed be due to the small series analysed.

By using direct sequencing, we performed a screen for germline mutations of $P A L B 2$ coding region and intronexon boundaries in $97 B R C A 1 / 2$ negative MBCs, previously identified in a population-based series of 108 MBCs [2]. Age at first $\mathrm{BC}$ diagnosis ranged between 35 and 90 years (mean 63.9 years), $25.8 \%$ of the patients reported a first-degree family history $(\mathrm{FH})$ of breast/ovarian cancer and $14.4 \%$ had a personal history of cancer(s) at sites other than breast. In particular, prostate $(28.5 \%)$ and bladder $(28.5 \%)$ carcinomas were the most frequently observed metachronous cancers. Table 1 shows all the $P A L B 2$ variants identified in our study. No truncating mutations were found. A novel missense variant, I1180T, was identified in a young man diagnosed with BC at 42 years of age and with negative FH. In silico analysis (PolyPhen, SIFT, Align-GVGD and Pmut) showed that I1180T is likely to be deleterious, since it occurs in the WD40-4 conserved domain that regulates PALB2 interaction with BRCA2. This variant was not found in 90 male population controls analysed (Table 1). Three additional missense variants (Q559R, E672Q and G998E) and one synonymous (T1100T) variant, all previously 
Table 1 PALB2 genetic variants found in a population-based series of 97 BRCA1/2 negative MBCs and 90 healthy adult male population controls from Central Italy

\begin{tabular}{|c|c|c|c|c|c|c|c|c|}
\hline \multirow[t]{2}{*}{ Location } & \multirow{2}{*}{$\begin{array}{l}\text { Nucleotide }^{a} \\
\text { change }\end{array}$} & \multirow{2}{*}{$\begin{array}{l}\text { Amino acid } \\
\text { substitution }\end{array}$} & \multicolumn{2}{|c|}{$N$. heterozygotes $(\%)$} & \multicolumn{4}{|c|}{ In silico analysis } \\
\hline & & & Cases & Controls & PolyPhen & SIFT & A-GVGD & Pmut \\
\hline \multicolumn{9}{|l|}{ Coding $^{\mathrm{b}}$} \\
\hline Exon 4 & c. $1676 \mathrm{~A}>\mathrm{G}$ & p.Q559R & 24/97 (24.7) & $15 / 90(16.6)$ & Benign & Tolerated & Neutral & Neutral \\
\hline Exon 5 & c. $2014 \mathrm{G}>\mathrm{C}$ & p.E672Q & $11 / 97(11.3)$ & 9/90 (10) & Benign & $\begin{array}{l}\text { Affect protein } \\
\text { function }\end{array}$ & Neutral & Neutral \\
\hline Exon 9 & c. $2993 \mathrm{G}>\mathrm{A}$ & p.G998E & $11 / 97(11.3)$ & 9/90 (10) & $\begin{array}{l}\text { Possibly } \\
\text { damaging }\end{array}$ & $\begin{array}{l}\text { Affect protein } \\
\text { function }\end{array}$ & $\begin{array}{l}\text { Likely } \\
\text { deleterious }\end{array}$ & Pathological \\
\hline Exon 12 & c. $3300 \mathrm{~T}>\mathrm{G}$ & p.T1100T & $12 / 97(12.3)$ & $11 / 90(12.2)$ & - & - & - & - \\
\hline Exon 13 & c.3539T $>C$ & p.I1180T & 1/97 (1) & 0/90 (0) & $\begin{array}{l}\text { Possibly } \\
\text { damaging }\end{array}$ & $\begin{array}{l}\text { Affect protein } \\
\text { function }\end{array}$ & $\begin{array}{l}\text { Likely } \\
\text { deleterious }\end{array}$ & Pathological \\
\hline \multicolumn{9}{|c|}{ Non-coding ${ }^{\mathrm{b}}$} \\
\hline $5^{\prime} \mathrm{UTR}$ & c. $-47 \mathrm{G}>\mathrm{A}$ & - & $3 / 97$ (3) & - & - & - & - & - \\
\hline IVS3 & c. $212-58 \mathrm{~A}>\mathrm{C}$ & - & $12 / 97(12.3)$ & $11 / 90(12.2)$ & - & - & - & - \\
\hline IVS3 & c.212-49T $>C$ & - & 1/97 (1) & - & - & - & - & - \\
\hline IVS3 & c.212-46insT & - & 1/97 (1) & - & - & - & - & - \\
\hline
\end{tabular}

${ }^{a}$ Nucleotide ID: NG_007406.1, NCBI

b Novel variants are indicated in bold

reported [3], were identified in our series. Both in silico analysis and frequency in population controls indicated a neutral effect for Q559R and E672Q (Table 1). With regard to the G998E variant, in silico analysis predicted a deleterious effect, but its high frequency (10\%) in controls reduces the likelihood of a pathogenic role (Table 1). Furthermore, two novel (IVS3-49T $>$ C and IVS3-46insT) and two previously reported $\left(5^{\prime} \mathrm{UTR}-47 \mathrm{G}>\mathrm{A}\right.$ and IVS3-58A $>$ C) $[4,5]$ non-coding variants were identified (Table 1). In silico analysis (SpliceSiteFinder and SpliceSitePredictions) indicates that these variants do not affect splicing. Overall, a novel possibly damaging PALB2 mutation (I1180T) was found in $1 \%(1 / 97)$ of the MBCs analysed. Interestingly, $11.3 \%$ of the MBCs (11/97) were found to carry a combination of PALB2 variants, including Q559R, E672Q, G998E, T1100T and IVS3-58A $>$ C. Although these variants may be individually neutral, it cannot be excluded that a combination of variants may confer susceptibility for $\mathrm{MBC}$ as reported for $\mathrm{FBC}[9,10]$. However, the co-existence of these variants was observed in $6.6 \%(6 / 90)$ of our controls.

Founded on a large population-based series, our results do not indicate a major role of PALB2 on MBC susceptibility on the other hand they hint that $P A L B 2$ is deemed to have a role as moderate-penetrance gene at a comparable extent as for FBC. Functional studies are needed to better investigate the pathogenic role of the novel I1180T variant identified in our series. Furthermore, collaborative studies are required to evaluate whether, following a polygenic model, the co-existence of multiple PALB2 variants may act as low-penetrance alleles, thus explaining a subset of BRCA1/2 negative MBCs.

Acknowledgements We wish to thank Dr. Raffaele Palmirotta and all his staff of the Department of Laboratory Medicine \& Advanced Biotechnologies (IRCCS San Raffaele Pisana) for their precious suggestions and technical support. The study was supported by a grant from Associazione Italiana per la Ricerca sul Cancro (AIRC) to L.O. (IG 8713) and by Regione Toscana in the frame of the High-Risk Cancer Family Project.

\section{References}

1. Ottini L, Palli D, Rizzo S, Federico M, Bazan V, Russo A (2010) Male breast cancer. Crit Rev Oncol Hematol 73(2):141-155

2. Ottini L, Rizzolo P, Zanna I, Falchetti M, Masala G, Ceccarelli K, Vezzosi V, Gulino A, Giannini G, Bianchi S, Sera F, Palli D (2009) BRCA1/BRCA2 mutation status and clinical-pathologic features of 108 male breast cancer cases from Tuscany: a population-based study in central Italy. Breast Cancer Res Treat 116(3):577-586

3. Rahman N, Seal S, Thompson D, Kelly P, Renwick A, Elliott A, Reid S, Spanova K, Barfoot R, Chagtai T, Jayatilake H, McGuffog L, Hanks S, Evans DG, Eccles D, Breast Cancer Susceptibility Collaboration (UK), Easton DF, Stratton MR (2007) PALB2, which encodes a BRCA2-interacting protein, is a breast cancer susceptibility gene. Nat Genet 39(2):165-167

4. Cao AY, Huang J, Hu Z, Li WF, Ma ZL, Tang LL, Zhang B, Su FX, Zhou J, Di GH, Shen KW, Wu J, Lu JS, Luo JM, Yuan WT, Shen ZZ, Huang W, Shao ZM (2009) The prevalence of PALB2 germline mutations in BRCA1/BRCA2 negative Chinese women with early onset breast cancer or affected relatives. Breast Cancer Res Treat 114(3):457-462

5. Erkko H, Xia B, Nikkila J, Schleutker J, Syrjakoski K, Mannermaa A, Kallioniemi A, Pylkas K, Karppinen SM, Rapakko K, 
Miron A, Sheng Q, Li G, Mattila H, Bell DW, Haber DA, Grip M, Reiman M, Jukkola-Vuorinen A, Mustonen A, Kere J, Aaltonen LA, Kosma VM, Kataja V, Soini Y, Drapkin RI, Livingston DM, Winqvist R (2007) A recurrent mutation in PALB2 in Finnish cancer families. Nature 446(7133):316-319

6. Thellenberg C, Malmer B, Tavelin B, Grönberg H (2003) Second primary cancers in men with prostate cancer: an increased risk of male breast cancer. J Urol 169(4):1345-1348

7. Hemminki K, Scélo G, Boffetta P, Mellemkjaer L, Tracey E, Andersen A, Brewster DH, Pukkala E, McBride M, Kliewer EV, Chia K-S, Pompe-Kirn V, Martos C, Jonasson JG, Li X, Brennan $P$ (2005) Second primary malignancies in patients with male breast cancer. Br J Cancer 92(7):1288-1292
8. Sauty de Chalon A, Teo Z, Park DJ, Odefrey FA, kConFab, Hopper JL, Southey MC (2009) Are PALB2 mutations associated with increased risk of male breast cancer? Breast Cancer Res Treat. doi:10.1007/s10549-009-0673-x

9. Chen P, Liang J, Wang Z, Zhou X, Chen L, Li M, Xie D, Hu Z, Shen H, Wang H (2008) Association of common PALB2 polymorphisms with breast cancer risk: a case-control study. Clin Cancer Res 14(18):5931-5937

10. Cao AY, Yu KD, Yin WJ, Jin W, Di GH, Shen ZZ, Shao ZM (2009) Five common single nucleotide polymorphisms in the PALB2 gene and susceptibility to breast cancer in eastern Chinese population. Breast Cancer Res Treat. doi:10.1007/ s10549-009-0637-1 